\title{
The Rectification Measures on High Fault of 10kV High Voltage Isolation Switch
}

\author{
Miao Hui ${ }^{1}$, Jin Jingxin ${ }^{2}$, Zhang Hua ${ }^{1}$, Zheng Wanyi ${ }^{3}$, Zhu Yuanda ${ }^{3}$, Wang Chuang ${ }^{1}$, Cheng \\ Xingjun $^{1}$, Wang Zhaoxia ${ }^{1}$, Liu Chang ${ }^{1}$, Yang Xiaolei ${ }^{1}$, Yuan Chengye ${ }^{1}$ \\ ${ }^{1}$ Fushun Power Supply Company, Liaoning Electric Power Company Limited, State Grid, China \\ ${ }^{2}$ Dandong Power Supply Company, Liaoning Electric Power Company Limited, State Grid, China \\ ${ }^{3}$ Skills Training Centre, Liaoning Electric Power Company Limited, State Grid, China
}

Keywords: high voltage isolating switch, failure rate, wiring terminal, pile head

\begin{abstract}
The equipment mainly includes isolating switch, circuit breaker, conductor, insulator, arrester and measurement and control protection device. According to the survey, there were 180 failures in 2017, and the failure rate of the high voltage isolation switch was $10.53 \%$. In order to improve the power supply reliability, the high voltage isolation switch was rectified. Through the high voltage isolating switch terminals and pile head effective contact area, the terminal and pile head interface pressure, these two aspects are improved, the failure rate of high pressure isolating switch is reduced, the time of outage frequency and power outages are reduced, power supply reliability is enhanced obviously, service brand image of state grid is set up.
\end{abstract}

\section{Introduction}

The power distribution equipment on the $10 \mathrm{kV}$ column mainly includes the isolating switch, circuit breaker, conductor, insulator, arrester, measuring and controlling protection device, as well as the electric operating mechanism of circuit breaker operation and protection. The $10 \mathrm{kV}$ isolation switch is a power distribution switch device. The isolation switch includes a set of incoming and outgoing isolation switches and a set of ground isolation switches. Incoming line and off-line isolating switch function has an obvious cut-off point in connection with other electrical connections during the shutdown or overhaul to ensure safety.

At present, there are $10 \mathrm{kV}$ isolation switch 17090 groups in Fushun power supply company. The failure rate of $10 \mathrm{kV}$ isolation switch is still very high in 2017, and the statistics of accident rate are shown in table 1.

Table 1 The failure rate statistics of $10 \mathrm{kV}$ high voltage isolation switch company in 2017

\begin{tabular}{c|c|c|c|c|c}
\hline serial number & region & voltage & $\begin{array}{c}\text { Number of isolated } \\
\text { switches (group) }\end{array}$ & $\begin{array}{c}\text { Failure } \\
\text { frequency }\end{array}$ & Failure rate (\%) \\
\hline 1 & DongZhou & $10 \mathrm{kV}$ & 3610 & 25 & 6.92 \\
\hline 2 & XinFu & $10 \mathrm{kV}$ & 2360 & 17 & 7.2 \\
\hline 3 & WangHua & $10 \mathrm{kV}$ & 1480 & 21 & 14.18 \\
\hline 4 & HeBei & $10 \mathrm{kV}$ & 3730 & 35 & 9.4 \\
\hline 5 & KaiFaqu & $10 \mathrm{kV}$ & 2720 & 37 & 13.6 \\
\hline 6 & QingYuan & $10 \mathrm{kV}$ & 1560 & 26 & 16.67 \\
\hline 7 & XinBin & $10 \mathrm{kV}$ & 1630 & 19 & 11.65 \\
\hline & Sum & & 17090 & 180 & 10.53 \\
\hline
\end{tabular}

According to the requirement of the power supply reliability will be increased by Fushun power supply company, management level of $10 \mathrm{kV}$ line is promoted comprehensively, the failure rate of $10 \mathrm{kV}$ high voltage isolating switch was $10.53 \%$ in October 2017 . In order to improve power supply reliability and reduce switch failure rate, research, analysis and corrective measures are conducted. 


\section{Finding the Cause of the High Failure Rate}

\subsection{Classification by Fault Type}

From the aspect of line fault, the fault categories of 180 trips were classified and analyzed by this paper in 2017. The survey was shown in table 2, and the arrangement diagram was drawn, it is shown in figure.1.

Table 2 Classification questionnaire of 10kV circuit tripping from January to December in 2017

\begin{tabular}{c|c|c|c}
\hline The serial number & Problem category & Frequency (number) & Percentage (\%) \\
\hline 1 & equipment & 136 & 75.6 \\
\hline 2 & conductor & 24 & 13.3 \\
\hline 3 & insulator & 12 & 6.7 \\
\hline 4 & break & 6 & 3.3 \\
\hline 5 & other & 2 & 1.1 \\
\hline
\end{tabular}

Analysis results: From table 2, the equipment failure causes tripping times as high as 136 times, that's $75.6 \%$ of the total number in the 180 times, it is the key to impact high failure rate of $10 \mathrm{kV}$ high voltage isolation switch. So what kind of the line equipment is the reason? Let's do the analysis again.

\subsection{Classification by Equipment Category}

According to the investigation of the equipment failure caused by $10 \mathrm{kV}$ circuit tripping, from January to December, the equipment fault rate of the high voltage isolation switch caused by the transportation and inspection department checked in 2017. The statistics are shown in table 3:

Table 3 The problem of $10 \mathrm{kV}$ equipment caused the line trip from January to December in 2015

\begin{tabular}{c|c|c|c}
\hline The serial number & Problem category & $\begin{array}{c}\text { Frequency } \\
\text { (number) }\end{array}$ & Percentage(\%) \\
\hline 1 & Isolating switch & 110 & 80.9 \\
\hline 2 & transformer & 17 & 12.5 \\
\hline 3 & Metering device & 5 & 3.7 \\
\hline 4 & Lightning protection device & 3 & 22 \\
\hline 5 & other & 1 & 0.7 \\
\hline
\end{tabular}

Conclusions: From table 3, isolating switch fault is the main problems for affecting high failure rate of $10 \mathrm{kV}$ line tripping, that is $80.9 \%$ of tripping rate, then what kind of failure for isolating switch? The fault categories of isolating switches were investigated and analyzed.

\subsection{Analyzing the Fault Location of the Isolating Switch}

Below is the part name of the isolating switch, it is shown in Figure.1.

The team members analyzed the failure of the isolating switch in 2017, causing 110 times circuit tripping, according to the fault location of the equipment, a classified survey was conducted, it is shown in table 4.

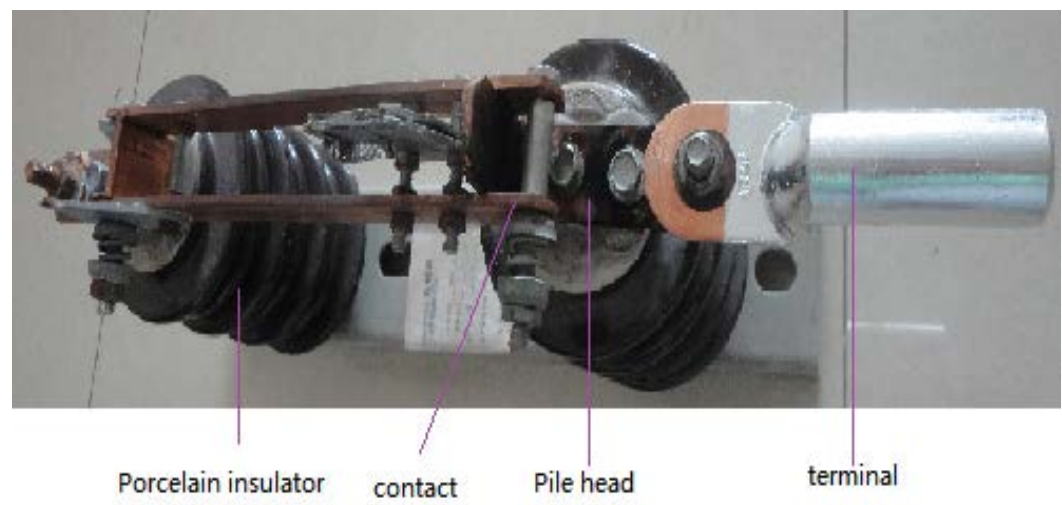

Fig.1. Part name of the isolating switch. 
Table 4 10kV breakdown switch fault classification questionnaire from January to December in 2017

\begin{tabular}{c|c|c|c}
\hline The serial number & Problem category & Frequency (number) & Percentage (\%) \\
\hline 1 & Pile head & 48 & 43.6 \\
\hline 2 & terminal & 36 & 32.7 \\
\hline 3 & contact & 18 & 16.4 \\
\hline 4 & Porcelain insulator & 6 & 5.5 \\
\hline 5 & other & 2 & 1.8 \\
\hline
\end{tabular}

Analysis results: From table 4, during 110 times line tripping caused by the failures of isolating switch in 2017, "the damaged pile head " and "the damaged terminal" is 84 times, that is $76.3 \%$ of the total tripping rate, it is the main reason to influence high failure rate of $10 \mathrm{kV}$ high voltage isolating switch.

Terminals and pile head interface pressure is small, it is not for examination and using excessive copper and aluminum terminals and terminal blocks have not reached the national standard, screw isn't tighten, environment and humidity exceed certain limits. The assembly point isn't mastered, the load current is large, terminal and pile head contact area is small, and size is small. Therefore, there are reformed main problems: 1 . The effective contact area between the terminals and pile tip is small; 2 . The contact surface pressure between terminal and pile is small.

\section{Determining the Rectification Plan}

\subsection{The Effective Contact Area Between the Terminals and Pile Tip is Small}

For effective contact area between terminal and pile head is small, three rectification plan is put, through researching and experiment, efficiency, economy and practicability is comprehensively compared, the optimal rectification plan is determined, it is shown in table 5.

Table 5 Rectification plan evaluation form

\begin{tabular}{|c|c|c|c|}
\hline The serial number & 1 & 2 & 3 \\
\hline plan & Increasing the pile head & $\begin{array}{l}\text { Increasing and } \\
\text { broadening the pile head }\end{array}$ & $\begin{array}{l}\text { Installing the wiring } \\
\text { terminal of the equipment }\end{array}$ \\
\hline Solutions & $\begin{array}{l}\text { Increasing the contact } \\
\text { surface of pile head } \\
\text { from } 30 \mathrm{~mm}\end{array}$ & $\begin{array}{l}\text { Pile head is lengthened } \\
30 \mathrm{~mm} \text { and widened } \\
31 \mathrm{~mm} \text {,then the contact } \\
\text { surface is increased. }\end{array}$ & $\begin{array}{l}\text { Install a wiring terminal on } \\
\text { the other side of the pile }\end{array}$ \\
\hline Temperature rise & More than $1^{\circ} \mathrm{C}$ & Less than $1^{\circ} \mathrm{C}$ & More than $1^{\circ} \mathrm{C}$ \\
\hline \multicolumn{4}{|l|}{ test } \\
\hline Project analysis & $\begin{array}{l}\text { If the pile head and } \\
\text { contact area increases, } \\
\text { contact pressure of the } \\
\text { growth part is small, and } \\
\text { the contact is not good, } \\
\text { resulting in rising } \\
\text { temperature, effective } \\
\text { contact result doesn't } \\
\text { reach }\end{array}$ & $\begin{array}{l}\text { After length and width, } \\
\text { due to the increasing of } \\
\text { the part is tightly around } \\
\text { the screw, the contact } \\
\text { pressure correspondingly } \\
\text { increases, it has good } \\
\text { effect }\end{array}$ & $\begin{array}{l}\text { Increasing the connecting } \\
\text { terminal, although the } \\
\text { contact area is increased, } \\
\text { but the wire diameter is } \\
\text { very small, the wire can't } \\
\text { be fastened, causing the } \\
\text { wire to loose, the contact is } \\
\text { not good, and the } \\
\text { temperature rising exceeds } \\
\text { the standard }\end{array}$ \\
\hline cost & 20 Yuan & 20 Yuan & 20 Yuan \\
\hline The selected plan & not choose & choose & not choose \\
\hline
\end{tabular}

Conclusion: Through the field test, the length and width of the pile head is increased, and the contact area is increased by the test analysis. 


\subsection{The Pressure of the Connecting Terminal and Pile Tip is Small}

Two rectification plans are proposed for the small pressure of terminal and pile, it is shown in table 6.

Table 6 Rectification program evaluation form

\begin{tabular}{l|c|c}
\hline The serial number & Adding screw in center & Adding screw on both sides \\
\hline plan & $\begin{array}{c}\text { Adding a screw to the hole to } \\
\text { increase the pressure of the } \\
\text { contact surface on the original } \\
\text { basis. }\end{array}$ & $\begin{array}{c}\text { Adding the copper pad and screws to } \\
\text { increase the pressure on the contact } \\
\text { surface without damaging the isolation } \\
\text { switch. }\end{array}$ \\
\hline Pressure test & Less than 120N & More than 120N \\
\hline Project analysis & $\begin{array}{c}\text { While increasing the contact } \\
\text { pressure, the contact surface is } \\
\text { reduced, resulting in reducing } \\
\text { load flow. }\end{array}$ & $\begin{array}{c}\text { The pressure of the two is increasing } \\
\text { without breaking the contact surface of } \\
\text { the terminals and the pile head. }\end{array}$ \\
\hline cost & 20 Yuan & Ten Yuan \\
\hline
\end{tabular}

\subsection{Conclusions}

Group members test analysis respectively in field. Screws are added to increase pressure without damaging the terminal and pile head interface, then pressure is more than $120 \mathrm{~N}$.

\section{Implement the Rectification Plan}

\subsection{Increasing and Broadening the Pile Head}

In order to increase the effective contact area between the isolation switch and the terminal, according to the field measurement of the isolation switch, the pile head should be extended to $83 \mathrm{~mm}, 46 \mathrm{~mm}$ width and $5 \mathrm{~mm}$ thick. According to the design process, it is shown in figure. 2 and figure.3.

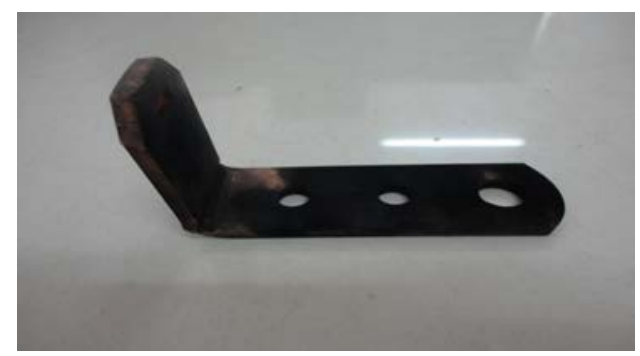

Fig.2. The terminal before improvement

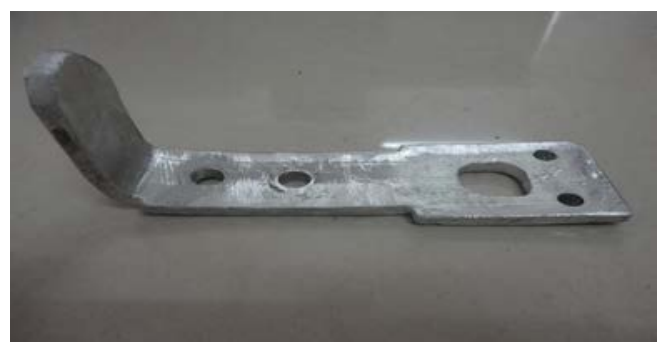

Fig.3. The terminal after improvement

\subsection{Adding Screws on Both Sides}

According to the spot size of the terminal, after discussion, the processing diagram of the wiring terminal is drawn. And the terminals are punched. it is shown in figure 4 and figure 5 . 


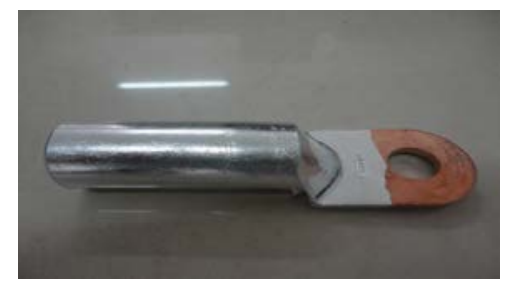

Fig.4. The terminal before improvement

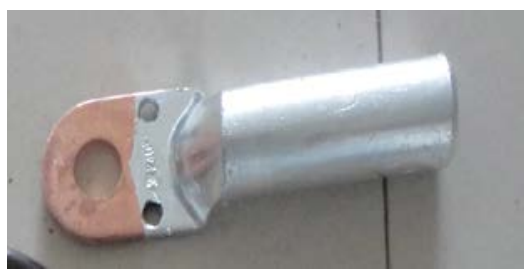

Fig.5. The terminal after improvement

\subsection{The Composition of the Modified Isolation Switch}

After rectification, the composition of the isolation switch is shown in figure.6.

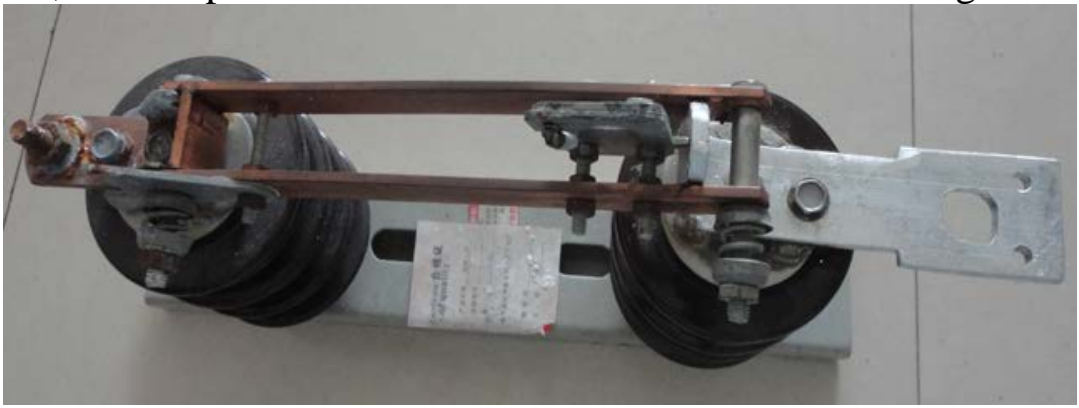

Fig.6. The terminal after improvement

\section{Operation After Rectification}

Transformation of isolating switch is used in Kai Faqu power supply, $10 \mathrm{kV}$ trips are counted, recorded, analyzed from June to September. $10 \mathrm{kV}$ total trips are 34 times from January to June, trip number is two with burned isolating switch, good results are achieved, the failure rate of $10 \mathrm{kV}$ high voltage isolating switch also fell from $10.53 \%$ to $5.9 \%$.

\subsection{Economic Benefits}

For Fushun power supply, the damaged isolating switch number was 84 by the damage of pile head and wiring terminal in 2017, for each set of isolating switch 230 Yuan, the loss is 19320 Yuan. The each set of isolating switch cost of the pile head and terminal is 30 Yuan, so that the savings will be 84* (230-30) = 16800 Yuan during 2017 and 2018.

\subsection{Social Benefits}

After Reducing the damage to isolating switch, fault tripping rate of $10 \mathrm{kV}$ line is greatly reduced, the frequency and time of power outage are reduced, power supply reliability enhanced obviously, state grid service brand image is set up.

\section{Conclusions}

The main content of distribution safety management is to reduce the fault of isolating switch and rectify isolation switch. Therefore, the concerned departments should fully understand the common fault types, performance and the reasons for isolating switch, and the isolating switch selection, installation and routine maintenance work is completed, also the problem is rectified. So the stable operation of the isolating switch and safety of the people is ensured. 


\section{References}

[1] Luo Liyang. Operation and accident handling of isolation switch in power distribution network. GuiZhou power technology. 2014 (7).

[2] $\mathrm{Wu}$ Tingzhu. Operation and accident handling of isolated switches in power distribution network. Technology and market. 2016 (6).

[3] Lu Guanglong. On the operation of isolating switches in power distribution network and the measures to deal with accidents. Low carbon world. 2017 (2). 